\title{
Employee Discipline Enhances Employee Engagement: An Affective Shift Model Perspective - A Literature Review
}

\author{
Article by Adamson Mukhalipi \\ PhD in Management - HR specialization \\ E-mail: adamsonmukhalipi@ymail.com
}

\begin{abstract}
Purpose: The purpose of this document is to propose that employee discipline be considered as a factor in employee engagement.

Design/Methodology/Approach: This conceptual review focuses on the research evidence showing the mediating role of employee discipline in enhancing employee engagement. The affective shift model helps us understand the relationship between employee discipline and employee engagement.

Findings: The author proposed that based on the affective shift model, employee discipline be considered as employee engagement and employee disengagement.

Recommendations: It is suggested that Human Resource Department should develop and put in place an engagement Plan targeting such employees to help them to quickly adjust and become productive and active, take part in decision making as they become committed in the realization of the organizational strategic objectives. Further, the author recommend that a detailed comparative study targeting both private and public organizations be conducted to assess the effect of discipline in enhancing employee engagement and also that an exploratory study be conducted to determine the effect of progressive discipline on employee engagement in organization.

Originality/Value: The author suggests that Human Resource Department should develop an engagement plan targeting disciplined employees with the view of helping them to quickly become productive and active, take part in decision making and become committed in the realization of the organizational strategic objectives.
\end{abstract}

Keywords: Employees, Discipline, Disengagement, Engagement, Commitment, Involvement.

\section{Introduction}

Globally there is a deal of interest in the concepts of employee engagement and employee performance (Ivan and Cary, 2009). During the past twenty (20) years, scholars in the psychology field have been researching engagement (Catherine, Rick Krestin, Amanda and Emma, 2013). However, it is only very recently that scholars in Human Resource Management have developed interest to the topic and this has led to the emergence of studies aimed at examining the implications of engagement (Catherine, Rick Krestin, Amanda and Emma, 2013) Further, Catherine, Rick Krestin, Amanda and Emma (2013) posit that studies aimed at analyzing engagement from labour process, critical management studies and collectivist standpoint have been developed (Jenkins and Delbridge, 2013). These studies have challenged the unitary assumptions which underpinned much of the extant research on engagement, located engagement within the broader setting of ongoing debates within HRM and organizational studies literature concerning structure, agency and the employment relationship (Truss et al. 2013).

It is from the above background that a lot of articles in engagement on the part of HRM which have been written and published (Catherine, Rick Krestin, Amanda and Emma, 2013) covering the following topics: Human Resource strategy and how it link to engagement, implications of engagement within the context of human resources development, employee engagement and job design, leadership and engagement, engagement's cultural and psychological roots, engagement in the context of multinational corporations and employee engagement and collectivism (Catherine, Rick Krestin, Amanda and Emma, 2013).

However, whereas (Naval and Brij, 2015) explain that the social exchange and job characteristics theories depicts HR practices which result in a high level employee performance but very little has been 
said on how employee discipline enhance employee engagement. Therefore, based on the affective shift model, this paper will explore how employee discipline enhance employee engagement. The article will define employee engagement, explain the drivers of employee engagement, employee disengagement, provide a brief explanation on the affective shift model and the mediation role of employee discipline in enhancing employee engagement or employee disengagement, definition of discipline will be given, type of discipline applied in organizations and how these impact on employee engagement or employee disengagement will also be discussed.

\section{Objectives \& research methodology}

The article aims to establish an understanding how employee discipline enhance employee engagement with the help of literature review. Literature reviewed in this paper was sourced from the general internet searchers, text books, Disciplinary Codes and journals from open line publications.

\section{Limitations}

There are limitations to this review of the literature. Research was also limited to peer-reviewed business, organizational psychology, and management journals, online journals to identify the type of discipline applied at places of work and how it impacts on employee engagement based on the affective shift model with the help of review of literature.

\section{Literature review}

Onesmus and Muathe (2016) and Balakrishnan and Dr. Masthan (2013) state that employees are the most valuable resource organizations should possess. Globally there has been an increase in talent war and therefore each organization are ensuring that they attract the best talented employees and retain them. Organizations can acquire most asset similar to what the competitor has but could not cope with the skill and talent of the competitor (Balakrishnan and Dr. Masthan, 2013). The situation is now reaching an alarming level as organizations are targeting the same pool of talented and experienced employees across the world. Therefore, as Pandita and Bedarkar (2014) note the toughest challenge Chief Executive Officers (CEO), Human Resources and other business leaders of many organizations face is to ensure that when employees report for work, they execute their job, physically, mentally and emotionally (Onesmus and Muathe, 2016). This means that organizations must ensure that they have an engaged workforce at all times who are willing to contribute positively towards achieving their organizational goals and in turn attain the set objectives.

\section{Employee enagement}

Priya and Dr. Krisnaveni (2012) observe that the term employee engagement has attracted much attention in the business world with intensive marketing by HR firms. Despite, most websites, research papers, books and conferences give evidence to the availability of literature on employee engagement, rigorous research is still required (Luthans and Peterson, 2002; Cartwright and Holmes, 2006, Joo and Maclean, 2006). This gap has resulted in different interpretation of the term employee engagement by different scholars, consultants, and academic researchers. SABPP, Fact sheet, (2014) state that some of these definitions are conflicting each other. This lack of consensus in academic and consulting on the definition of employee engagement, on how to measure it, and how to develop programmes to improve it has led to lack of comparable benchmarking (SABPP, Fact sheet, 2014).

Nitin, (2007); Abdul, Rizwan, Muhammad and Ali, (2014) and Onesmus and Muathe, (2016) state that Kahn (1990) the employee engagement guru defines employee engagement as "the harnessing of organizational members to their respective work roles in order to get engaged, employ and express themselves physically, cognitively, and emotionally in their role performances" The key message from this definition is that an employee should be present at work both physically and emotionally. Further, Mrs. Priya and Dr. Krishnaveni (2012) and Onesmus and Muathe, (2016) state that the only study that empirically tested Kahn's model, May et al (2004) found that there was a correlation between meaningfulness, safety and availability and engagement and also proved that psychological conditions affect employee engagement (See figure 1 below). The study also revealed that: job enrichment and role fit were positive predictors of meaningfulness; rewarding co-worker and supportive supervisor 
relations were positive predictors of safety, however adherence to co-worker and supportive norms and self-consciousness were negative predictors (Kular et al, 2008).

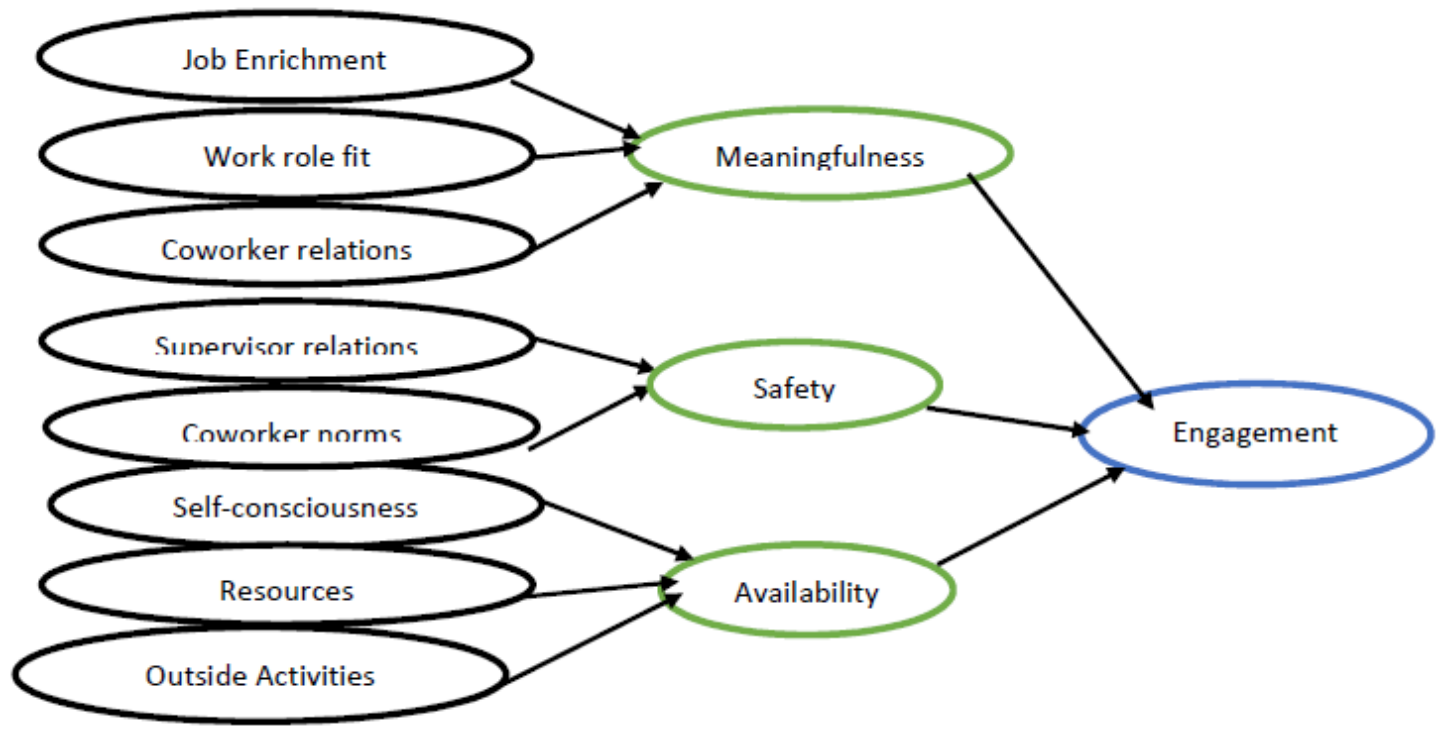

Figure 1. Path- analytical framework of engagement (Adapted from may et al, 2014, p. 25)

Meere (2005) in (Abdul, Rizwan, Muhammad and Ali, 2014) describes three levels of engagement as follows: 1) Engaged-Employees are passionate with their work and are profoundly connected to the organization. They are innovative and steer the organization forward. 2) Not engaged-employees report for work and participate but are not passionate about their work. 3) Disengaged-employees report for work but are unhappy to participate in any work. Meere (2005) postulates that disengaged - employees undermine the work of their collegues time. This shows that employee engagement is an individual's sense of purpose only evident to others in the display of personal initiative and effort directed towards the attainment of the organizational goals (Sathishkumar and Dr. Karthiikeyan, 2014).

Gallup (2005) in Ologbo C. Andrew and Saudah (2012) submitted that the more employees became engaged, the more they helped an organization to attract more talented people while disengaged employees would cost an organization such as lower productivity, higher absenteeism, recruitment and training cost. This was also observed by Bates (2004) who noted that half of the United States workforce who were disengaged costed the country's businesses a lot of productivity worth $\$ 300$ billion annually.

\section{Drivers of employee engagement}

The Insights Group limited's white paper, (2014), posit that sense of feeling valued and being involved in decision making, the employer's concern for employee health and well-being are the biggest drivers for engagement. Rath and Harter (2010) in Anita (2014), emphasizes that workplace well-being drives employee engagement.

Maclead and Nita (2008) in their report to the UK government on the benefit of employee engagement and the potential benefits, revealed that visible empowering leadership, engaging managers, employee participation and integrity were key enablers of employee engagement. Similarly, Anita J. (2014) points out that effective leadership affects employee engagement

Aon Hewitt model (as cited in Viktoria, 2014), defined and examined the following engagement drivers which are divided into six categories:

1. Work: Empowerment/Autonomy; employees feel they have accomplished their tasks.

2. People; Senior Leadership; Business Unit Leadership; Supervision; Collaboration.

3. Opportunities; Learning and development and also career progression.

4. Total Rewards; Brand/Reputation, Pay, Benefits; Recognition.

5. Company Practice; Communication, Diversity and Inclusion; Enabling Infrastructure; Performance

Management; Customer Focus; creativity and innovative, talent management and Staffing.

6. Quality of Life; Job Security; Safety; Work/Life Balance. 
Further, Anita (2014) (as cited in Viktoria, 2014), defined the following factors as facilitating employee engagement:

1. Work environment - such environment provides support for employees to focus on the job and conducive interpersonal relationship.

2. Leadership - effective leadership that promote self-awareness, transparency and internalized morale standards (Walumba et al, 2008 in Anita, 2014).

3. Team and co-worker - supportive and trusting interpersonal relationship promotes employee engagement.

4. Training and Career development - helps the employees to focus on work dimension.

5. Compensation - employees are motivated to achieve more by compensation or remuneration.

6. Organization policies - the extent to which employees are engaged is influenced by organization policies and procedures, structures and systems.

\section{Employee disengagement}

Sandeep et al, 2008 (as cited in Bates 2004 and Richman 2006) stipulate that research has established that the levels of employee engagement are on the decline and that this has resulted in a deepening disengagement among employees today. This is confirmed in a study conducted by Gallup Organization based on a large sample of the UK workforce (Buckingham 2001), which identified three discrete groups of employees namely; employees who are engaged, employees who are non-engaged and employees who are actively disengaged. The findings revealed that 63 per cent of sample are employees who are non-engaged. These employees were only engaged in doing what they were requested to do but were not bonded to the organization psychologically. Furthermore, such employees were instrumentally motivated; they could be tempted by other job offers from other organizations and attracted by financial incentives, but could be cynical about higher-order appeals to loyalty, 17 per cent of the sample, were engaged employees who are loyal, committed, productive and task-effective. On the other hand, 20 per cent of the sample, were employees who were actively disengaged employees, though they were physically present, but psychologically absent. These employees' demonstrated behaviours and attitudes that was negative, un co-operative and even hostile.

Sandeep et al (2008), observes that the discussion on employee disengagement is often focused on the negative influence it has on the organization. Kahn (1990, p. 701) defined personal disengagement as the person's preferred self-concurrent withdrawal and defense in behaviors that resulting in lack of physical, cognitive and emotional connection.

Further, Sandeep et al (2008) suggests that disengaged employees are not enthusiastic; they do not want to spend extra effort and do not believe in team work. Therefore, these employees with reduced engagement level, lack curiosity about their organization as they are not even interested the role the play in the organization. They exhibit poor interpersonal relationship towards their colleagues and managers (Wellins and Concelman 2005).

Similarly, Branham (2005, p. 4) posit that disengaged workers negatively influence morale and revenues of the organization; they often cause trouble, complain, and have accidents. Such employees bad mouth the organization and do not speak and treat customers well as their negative behavior affects client satisfaction and organizations end up losing the clients (Vajda and SpiritHeart 2008).

Sandy (2016) state that the Gallup researchers noted that actively disengaged employees cost American companies an estimated $\$ 300$ billion annually in the lost productivity. Disengaged employees usually actively express their unhappy feelings openly and their negative influence affect other team members and destroy achievements of engaged workmates (Gallup 2006). Disengaged employees are not connected to their job and are less efficient and less loyal to the organizations, they are also less not satisfied with their lives, and are worry more on job insecurity and experience stress more than their job than co-workers (Gallup 2001).

\section{Reasons why people disengage and quit}

Based on the findings of Kahn (1990, pp. 702-717), Branham (2005, pp.12-13), and Pech and Slade (2006, p. 24), Sandeep et al, 2008 suggest that it is possible to determine the potential sources or causes of employee disengagement and categorize them in the following groups: 
External environment causes, these are external challenges faced for employees, such as; unions or shareholders instability and insecurity arising from government, or possible opportunities, an unexpected job offer from outside, and so on;

Psychological causes and sources, lack of psychological; meaningfulness and safety at work, lack of identification with an organization, lack of trust, a sense of being undervalued, perceived inequities in terms of pay and performance, unrealized dreams, anxiety, stress and disinterest, etc.;

Organizational causes, such as organizational restructuring, inadequate cultural norms, policies and practices, transformational changes, traditions, (racial discrimination, unethical actions, unreasonable enforcement of authority, sexual harassment, etc.), overgrown bureaucracy, bad working conditions, leadership and poor management, low standards, lack of resources, and work complexity, etc.;

Other sources, for example, employee's substance abuse and illness, low standards, laziness, competency issues, poor interpersonal relationships leading to conflicts, etc.

Findings of Unpublished Saratoga Institute research showed that initiators of people's disengagement at work were an indication that they would want to quit the organization.

According to the research results, 35\% of employees quit due to insufficient leadership characteristics, $49 \%$ due to organizational environment, and $11 \%$ due to job characteristics. Only 5\% due to unavoidable reasons which included retirement, birth of a child, family issues, and so on. (Branham 2005, p. 24).

\section{Negative influence of disengagement}

Organizations should pay attention to employees who are disengaged, because they have great impact on their co-workers and their employer, just as employees who are engaged. Disengaged employees exhibit negative feelings and also experience health problems more often than engaged employees; they also transfer negative emotions to other employees hence influencing their behavior (Bakker and Demerouti, 2008). Disengaged employees do not satisfy their customers in terms of meeting the customer's needs and wants and their work output is lower than that of engaged employees (Towers Perrin 2003). Disengaged employees are more prone to accidents at work than engaged employees (Harter, Schmidt, Killham, and Asplund 2006, p. 28).

Further, disengaged employees do not recommend their company as a nice place to work for and do not recommend any of the company's products or services to others (Baumruk 2004, p. 49), they are not innovative and creative, and do not openly share new ideas with co-workers (Krueger and Killham 2007). Disengaged employees are neither satisfied or committed to their job and are likely to leave the organization any time (Saks 2006, p. 615). Branham (2005), says that such employees tend to absent themselves, exhibit tardiness or signs of withdrawal from the job or increased negativity. Similarly, (Pech and Slade, 2006) state that low morale, lack of energy, mistakes and lack of attachment to the job as symptoms of disengaged employees.

\section{The affective shift model}

Branham (2005), says that such employees tend to absent themselves, exhibit tardiness or signs of withdrawal from the job or increased negativity. This clearly shows that employee disengagement is real. Wilmar Schaufeli, (2013), observes that engagement waxes and wanes as a person moves through the working day, shifting from one task to another and being exposed to various kinds of events during the day (Sonnentag, Dormann and Demerouti, 2010). The affective shift model which is based on the assumption that both positive and negative affect have important functions for engagement and helps in understanding the engagement waxes and wanes.

This Affective Shift Model proposes that a core mechanism underlying the emergence of high engagement is as a result of the shift from negative to positive affect. Negative affect has motivating potential, meaning that it signals that things are not going well and that action should be taken. Subsequent effort then releases this motivating potential of negative affect and a shift towards a positive affective state occurs. Engagement is most likely to result when this up-regulation of positive affect is accompanied by a simultaneous down regulation of negative affect. So it is the dynamic interplay of positive and negative affect at work that produces work engagement. Bledlow et al. (2011) followed a group of 55 German ICT professionals for two weeks and demonstrated that - as predicted by their 
affective shift model - moving from negative events with negative mood to high-positive mood with high engagement. Although so far only one study has tested the affective shift model, the results are encouraging for explaining the dynamic nature of work engagement.

\section{Discipline}

Chris Vaden (2004), state that Discipline in an organization ensures productivity and efficiency. Further, discipline encourages harmony, co-operation among employees and boosts morale among for the employees. However, Fenley (1998) argues that management of workplace discipline remains a key problem in employee relations, and is one of the most discernible sources of conflict at work. Decenzo and Robbins (1999) define discipline as the organizational conditions in which employees align to organization's rules and standards of acceptable behavior. Redeker (1983) mention that discipline aims to create and maintain mutual respect and trust between management and the employees. He further notes that discipline could be a cost to the company in a long run if it is not well managed and these costs would include; lost time in preparing or attending court cases, legal costs, reduced productivity levels and increased expenses associated with replacing staff being disciplined. In order to determine the possible approaches in managing employee discipline at the workplace in order to enhance good corporate performance, Vonai, (2013) conducted a theoretical analysis of the types of disciplines that she felt could be incorporated by an organization without infringing on employee motivation and performance. The study concluded that most organizations and managers are under pressure from their superiors, competitors, customer care, and financial constraints and client demand, which results in taking disciplinary action on erring employees. Further, she notes that the way organizations handle disciplinary issues may have a bearing on employee behavior and attitude. She stresses that for any organization, employees are the first stake holders that should be given attention by management and treated like the best customer before attending to their customers' demands and meet other external requirements. Therefore, based on the punitive, corrective, revisionist and the metaphorical models of discipline, it was suggested that the disciplinary model management applies must not be disruptive to the employees' motivation and commitment See Chat 4.1 below). These views are supported by Fenley (1998) who stated that there are four models or theoretical approaches to discipline which are punitive, corrective, revisionist and metaphorical models. The analysis of different disciplinary approaches, pointed to the need for organizations to make discipline a corrective mechanism, and not a punishment tool.

\section{Discussion}

\section{Affective shift model, employee discipline and employee engagement}

It has already been noted above that the affective shift model proposes a core mechanism underlying the emergence of high engagement which is a shift from negative to positive affect. Negative affect has motivating potential, meaning that it signals that things are not going well and that action should be taken so that the positive affect is realized. Therefore, more effort is applied to shift negative affect towards a positive affective state to produce positive results.

Applying the Affective Shift model when dealing with disengaged employees who are not satisfied, not committed to the task, absent themselves at will, and have an intention to leave their organization (Saks 2006, p. 615) or do not market their company as a place to work for to their friends and less often recommend the products or services produced or offered by their organization (Baumruk 2004, p. 49), such employees are not innovative and are not willing to contribute or share any new ideas with coworkers (Krueger and Killham 2007). This therefore signals that things are not going well and that an action is needed. To address this, management in most public and private organizations resort to taking disciplinary measures against such employees with the view to improving productivity and efficiency levels of such employees. It is expected that after being disciplined, employees' behavior would shift from negative to positive affect.

Therefore, a review of the effect of the Punitive and Corrective Model in disciplining erring employee who are disengaged to determine whether disciplinary action would shift employee's negative behavior to positive affect as suggested by the Affective Shift Model is discussed below: 


\section{Application of discipline in line with the punitive model}

First and foremost, applying the Punitive Model in disciplining erring employees considers management as being "hard" in that management is willing and able to exercise prerogatives with little interference from trade unions and without substantial regard to the law or outside agencies (Fenley (1998). Fenley, 1998) observes that management uses punitive discipline to deter other employees from committing similar offences. Organizations and managers that apply this model, believe that employees are expected to obey rules because of fear of being punished which would ensue if they breached any of the rules or any clause of the disciplinary code. Fenley (1998) observes that the Punitive Model neglects the educational possibilities of a disciplinary policy in training employees to obey rules and as such adjudication by management is in most of the case prompt and final; dismissal take place without specific warning. Countervailing considerations such as effective union representation, legal, arbitrarily, and procedural rights would be marginal and of little consequence. The negative effect of this model is that it produces undesirable side effects in terms of worker resentment against the employer either through overt conflict or through other potential sources of disruption to work (Fenley, 1998). This may breed unnecessary tension in various units of an organization with employees spending more of their time focusing on non-productive issues. Therefore, the application of discipline in line with the punitive model does not show that a disengaged employee shifts from negative to positive in order to become an engaged employee as suggested by the Affective Shift Model. Instead, the employee becomes more disengaged as he or she serves suspension or accepts his or her dismissal from employment on disciplinary grounds. This is contrary to the general view held by Anita, 2014, who states that the extent to which employees are engaged is influenced by organization policies and procedures, structures and systems.

\section{Application of discipline in line with the corrective model}

On the other hand, applying the Corrective Model in disciplining erring employees foster selfdiscipline, action on the employer's part is designed to correct the individual rather than punish or instill fear. This model requires that Management communicates rules to all employees and that employees should accept rules and penalties which are designed to be applied fairly and consistently. The Code of Conduct and employment disciplinary code are used to create awareness among employees about certain behaviors which would lead to misconduct. Except in cases of gross misconduct, dismissals do not take place unless an employee is accorded an opportunity to modify his or her behavior. Therefore, adequate times are given as an opportunity for the employee to improve before a dismissal takes place, and lesser penalties for initial infractions (Fenley, 1998). The principles of "natural justice" are strictly observed and as such accused persons are accorded an opportunity to be heard, the right to be accompanied with a representative, the right of appeal, to question the facts as presented and the right to present a defense (Fenley, 1998). Therefore, the corrective model aims to establish whether rules or orders are reasonably related to the efficient and safe operation of company business. Further, management examines the degree of rule infraction, the employee's intent, his or her knowledge of the rule or standard, whether or not he or she made an honest mistake, and the personal impact of disciplinary action. Management also considers the employee's past service, his or her work and disciplinary record and psychological state. Since this model is based on the assumption that employees are willing to abide by well-established and equitable standards of behavior, application of discipline in line with the corrective model does shift the disengaged employee to become an engaged employee as suggested by the Affective Shift Model. This is supported by the general view held by Anita, 2014, that the extent to which employees are engaged is influenced by organization policies and procedures, structures and systems.

A review of the Disciplinary Code at Mopani Copper Mines Plc-Zambia revealed that both Corrective and Punitive Models are applied in administering discipline to erring employees (See Table 5.1 below).

The table shows that Category 1 offences most often are in line with the Corrective Model and Categories 2 and 3 offences most often are in line with the Punitive Model in that erring employees are placed on Severe Warning or Final Warning with suspension or summarily dismissed for committing Category 2 offences or are just summarily dismissed for committing Category 3 offences. However, a 
strange pattern depicted by Table 5.1 is that very few cases are considered under the Corrective Model and majority of the cases fall under Punitive Model.

Although a disciplinary code must be both just and uniformly administered to ensure that all individuals are treated in a fair and consistent manner, very little or nothing has been said on how the application of discipline either under punitive or corrective model at workplaces, result in enhancing employee engagement.

Table 5.1. Disciplinary models and penalties in administering discipline

\begin{tabular}{|c|c|c|}
\hline Corrective Model & Punitive Model & \\
\hline Category 1 & Category 2 & Category 3 \\
\hline $\begin{array}{l}\text { a) Poor Time Keeping: } \\
\text { reporting late for work, } \\
\text { leaving work place early, } \\
\text { loafing on duty, extended } \\
\text { or unauthorised breaks } \\
\text { during working hours etc. } \\
\text { b) Substandard/ Poor Work } \\
\text { Performance } \\
\text { c) At risk Behaviour: } \\
\text { Unintentional lapse } \\
\text { causing minor breach of } \\
\text { safety standards or } \\
\text { SafeWork procedure that } \\
\text { creates a hazard or injures } \\
\text { another person but not } \\
\text { likely to result in a Return } \\
\text { to Work Injury (RWI) or } \\
\text { Lost Time Injury (LTI) }\end{array}$ & $\begin{array}{l}\text { a) Absenteeism - Absence } \\
\text { from work without } \\
\text { permission, for the } \\
\text { whole or part of the } \\
\text { shift. } \\
\text { b) Abuse of Authority } \\
\text { c) Insubordination } \\
\text { d) Inefficiency } \\
\text { e) Negligence of Duty/ } \\
\text { Carelessness } \\
\text { f) Abusive Language } \\
\text { g) Refusing or Failure to } \\
\text { Obey/Carry out Lawful } \\
\text { h) Non Compliance with } \\
\text { Established Procedures } \\
\text { /Standing Instructions } \\
\text { i) At risk Behaviour and } \\
\text { related SafeWork } \\
\text { violations: } \\
\text { (1) Repeated breaches of } \\
\text { Category 1 Unsafe acts } \\
\text { (2) Breach of safety } \\
\text { standards that was not wilful } \\
\text { but could result in RWI or } \\
\text { LTI but not resulting into } \\
\text { permanent injury. } \\
\text { Unintentional / minor } \\
\text { violations of Fatal Hazard } \\
\text { Protocols and Life Saving } \\
\text { behaviours. } \\
\text { (3) Reporting for work or } \\
\text { Entering/or Attempting to } \\
\text { enter the Plant and Works } \\
\text { area under the influence of } \\
\text { alcohol with readings } \\
\text { between 1mg\%BAC and } \\
\text { 10mg\%BAC inclusive. } \\
\text { (4) Not wearing a seat belt } \\
\text { whilst driving a Company } \\
\text { vehicle/equipment. }\end{array}$ & $\begin{array}{l}\text { j) Willful loss/Damage to } \\
\text { Company property } \\
\text { k) At risk Behaviour: } \\
\text { (1) Sleeping on Duty } \\
\text { (2) Deliberate and intentional } \\
\text { breach of Health and Safety } \\
\text { Standards. } \\
\text { (3) Wilful breach of Fatal } \\
\text { Hazard Protocols and Life } \\
\text { Saving Behaviours. } \\
\text { (4) Breach of safety standards } \\
\text { likely to result in permanent } \\
\text { injury or fatality. } \\
\text { l) Absenteeism of ten (10) } \\
\quad \text { consecutive days } \\
\text { m) Unauthorised removal or } \\
\text { possession of property } \\
\text { belonging to the Company or } \\
\quad \text { contractor or another person. } \\
\text { n) Aiding and abetting } \\
\quad \text { unauthorised removal of } \\
\text { property as in (d) above. } \\
\text { o) Unethical Business Conduct: } \\
\text { (i) Failing to account for } \\
\text { Company property } \\
\text { (ii) Forgery, falsifying and } \\
\text { uttering: } \\
\text { (iii) False Evidence } \\
\text { (iv) Fraud: Gaining or } \\
\text { attempting to gain an advantage } \\
\text { (v) Corruption } \\
\text { (vi) Missapropriation } \\
\text { (vii) Breach or repudation of } \\
\text { contractual obligations } \\
\text { (1) Unauthorised disclo } \\
\text { (2) Concealing of information } \\
\text { (3) Deliberate breach or aiding } \\
\text { and abetting a breach of } \\
\text { procedures for personal gain or } \\
\text { selfish interest. } \\
\text { (g) Disorderly behaviour and } \\
\text { related offences such as fighting/ } \\
\text { riotous behaviour, horse play, }\end{array}$ \\
\hline
\end{tabular}




\begin{tabular}{|l|l|l|}
\hline & & $\begin{array}{l}\text { threatening violence or acting } \\
\text { violently, assault or attempted } \\
\text { assault. } \\
\text { (h) Unconstitutional Industrial } \\
\text { Action. } \\
\text { (1) Strike action } \\
\text { (2) Incitement to strike } \\
\text { (3) Picketing } \\
\text { (4) Intimidation } \\
\text { (5) Sabotage } \\
\text { (i) Racism } \\
\text { (j) Alcohol or Drug related } \\
\text { offences NB: The punishable } \\
\text { minimum level of intoxication } \\
\text { shall be 11mg\% BAC. }\end{array}$ \\
& & \multicolumn{2}{|l}{} \\
\hline $\begin{array}{l}\text { PENALTIES: } \\
\text { CATEGORY 1 }\end{array}$ & CATEGORY 3 \\
\hline $\begin{array}{l}\text { a) Unrecorded Warning } \\
\text { b) Recorded Warning } \\
\text { c) Severe Warning } \\
\text { d) Final Warning } \\
\text { e) Summary Dismissal }\end{array}$ & $\begin{array}{l}\text { Sanctions in order of } \\
\text { severity are: } \\
\text { (a) Severe Warning /plus } \\
\text { suspension } \\
\text { (b) Final Warning / plus } \\
\text { suspension } \\
\text { (c) Summary Dismissal }\end{array}$ & Summary Dismissal \\
\hline $\begin{array}{l}\text { Note that it is NOT mandatory to progress an employee through each step automatically. For } \\
\text { example, an employee who is on a clean record or Severe Warning may, if the gravity of the } \\
\text { offence warrants it be progressed to Final warning or Summary Dismissal }\end{array}$ \\
\hline
\end{tabular}

Source: MCM disciplinary code and grievance procedure for staff (2016).

\section{Concluding remarks}

It has been learnt that engaged-employees work with passion and feel a profound connection to their organization. These employees drive innovation and move the organization forward. On the other hand, Disengaged-employees are unhappy at work, absent themselves and exhibit negative behavior towards supervisors, co-workers and customers. Therefore, abased on the affective shift model, the behavior exhibited by the disengaged employees need to be corrected in order to shift such behavior from negative to positive affect. This correction is done through disciplinary action taken against such employees by managers. However, it has been noted that organizations that follow Punitive Model in disciplining erring employees (disengaged employees), produce more disengaged employees. On other hand, organizations that confine to Corrective Model as a way of disciplining erring employees (disengaged employees), produces engaged employees.

Close review of literature, show that a gap exists in the current role of HR practitioners who do not take an active role in helping employees disciplined through punitive model to be re-engaged on time after being disciplined.

Therefore, it is suggested that Human Resource Department should develop an Engagement Plan targeting employees disciplined through the punitive model with the view of helping them to quickly adjust, become productive and active, take part in decision making and become committed in the realization of the organizational strategic objectives.

Further, the author recommend that a detailed comparative study targeting both private and public organizations be conducted to assess the effect of discipline in enhancing employee engagement or employee disengagement and also that an exploratory study be conducted to determine the effect of progressive discipline on employee engagement or employee disengagement in organizations. 
DOI: $10.21522 /$ TIJMG.2015.04.01.Art006

ISSN: $2520-310 \mathrm{X}$

\section{References}

[1]. Abdul, Rizwan, Muhammad and Ali (2014), 'A Critical Review of Model and Theory of Employee Engagement' Science International (Lahore), 26 (2) pp. 821-824.

[2]. Anita J. (2014) Determinants of Employee Engagement and their impact on employee performance, International Journal of Productivity and Performance Management, Vol 63, No. 3, pp. 308-323r Emerald Group Publishing Limited.

[3]. Arnold B. Bakker (2011) 'An Evidence - Based Model of Work Engagement' Association Psychological Science, Vol 20 No. 4 pp265-269.

[4]. A.S. Sathishkumar and Dr. P. Karthiikeyan (2014), 'Role of Quality Management Practices in Employee Engagement and its impact on Organizational Performance' Journal of Business Management and Social Sciences Research (JBM\&SSR), Vol 3, No. 10, pp. 1-5.

[5]. Bakker and Demerouti (2008), "Towards a Model of Work Engagement", Career Development International, 13, pp. 209-223.

[6]. Bates S. (2004), Getting engaged: Half of your workforce may be just going through the motions. HR Magazine, 49: 44-51

[7]. Baumruk, R. (2004) 'The missing link: the role of employee engagement in business success', Workspan, Vol 47, pp48-52.Fenley A. "Models, styles and metaphors: understanding the management of discipline", Employee Relations, 1998; 20: 353.

[8]. Buchanan, D. and Huczynski, A. (2004) Organisational Behaviour. An introductory text, $5^{\text {th }}$ ed. Harlow, FT/Prentice Hall.

[9]. Buckingham, M. (2001) 'What a waste', People Management, 11 October, pp36-39.

[10]. Catherine, Rick Krestin, Amanda and Emma (2013), Employee Engagement in Theory and Practice, CPI Group (UK) Ltd, Wolverhampton.

[11]. Decenzo DA, Robbins SP. Human Resources Management, 6th Edition, John Wily and Sons, Inc, New York, 1999; P. 401.

[12]. Delbridge R, Keenoy T (2010). „Beyond Managerialism? Int. J. Hum. Resour. Manage. 21:799-817.

[13]. Dr Hammand Alshammari (2015) 'Workplace Productivity through Employee Workforce Engagement: A Review Study' International Journal of Business and Social Science, Vol 6, No. 12, pp. 156-162.

[14]. Dr. Naval Garg and Dr. Brij Sharma (2015), The Mediating Role of Employee Engagement in the Relationship between High Performance Work Practices and Job Performance, NMIMS Management Review, Volume XXVII April-May 2015, pp. 85-102.

[15]. Elena Heikkeri (2010), Roots and Consequences of the Employee Disengagement Phenomenon, Saimaa University of Applied Sciences, Lappeenranta.

[16]. Gallup Organization (2005), Employee Engagement: The Engagement side of the Human sigma Equation Retrieved from www.Gallup.com on 12 September 2016.

[17]. Harter, J.K., Schmidt, F.L. and Hayes, T.L. (2002) 'Business-unit level relationship between employee satisfaction, employee engagement, and business outcomes: a meta- analyses, Journal of Applied Psychology, Vol 87, pp268-79.

[18]. Harter, J.K., Schmidt, F.L. and Keyes, C.L. (2002) 'Well-being in the workplace and its relationship to business outcomes: A review of the Gallup studies', in Keyes, C.L. and Haidt, J. (Eds) Flourishing: The Positive Person and the Good Life, pp205-224. American Psychological Association, Washington D.C.

[19]. Hewitt Associate (2004), Employee engagement at double digit growth companies. Research Brief.

[20]. Ivan T. Robertson and Cary L. Cooper (2009), 'Full engagement: the integration of employee engagement and psychological well-being', Leadership and Organizational Development Journal, Vol 31 No 4. 2010 pp. 324336.

[21]. Jenkins S. and Delbridge, R. (2013) 'Context Matters: Examining 'Soft' and 'Hard" Approaches to Employee Engagement in Two Workplaces', International Journal of Human Resource Management, 24 14:268279.

[22]. Kahn W. A. (1990), Psychological conditions of personal engagement and disengagement at work. Academy of Management Journal, 33, 692-724.

[23]. Kular, S., Gatenby, M., Rees, C., Soane, E. \& Truss, K. (2008). Employee Engagement: A Literature Review. Kingston Business School, Kingston University Working Paper Series No 19, October 2008. 
[24]. May DR, Gilson RL, Harter LM (2004). The psychological conditions of meaningfulness, safety and availability and the engagement of the human spirit at work. J. Occup. Organ. Psychol. 77:11-37.

[25]. Milkovich GT, Boudreau. Personnel Human Resource Management, All India Traveler Bookseller, New Delhi, 1998.

[26]. Mopani Copper Mines Plc (2016) Disciplinary Code and Grievance Procedure for Senior Staff.

[27]. Ologbo C. Andrew and Saudah (2012), 'Individual Factors and Work Outcomes of Employee Engagement' Procedia - Social and Behaviour Sciences 40, Elsevier Ltd, pp. 498-508.

[28]. Onesmus Kamau and Muathe SMA (2016), 'A Critical Review of Literature on Employee Engagement Concept' International Journal of Research in Social Sciences, Vol 6. No. 3, pp. 1-8

[29]. Padmakumar, R. \& Prabhakar Gantasala, V. (2011). The role of employee engagement in work-related outcomes. Interdisciplinary Journal of Research in Business, 1(3), 47-61.

[30]. Redeker J. Discipline: Policies and Procedures, Bureau of National Affairs, Washington, DC, 1983; P. 211.SABPP, Fact sheet, (2014), Employee Engagement, Number 2014/9, pp. 1-17.

[31]. Saks, A. M. (2006), 'Antecedents and Consequences of Employee Engagement' Journal of Managerial Psychological, 21 (7), 600-619.

[32]. The Insights Group Ltd (2014), 'White Paper - Employee Engagement'

[33]. Truss, C. Mankin, D. and Kelliher, C. (2012) Strategic Human Resource Management, Oxford: Oxford University Press.

[34]. Viktoria, Ali Taha (2014), 'Conceptualization and overview of current researches on employee engagement' Economy and Society Environment, Faculty of Management, University of Pres'ov.

[35]. Vonai Chirasha (2013) 'Management of Discipline for good Performance: A theoretical perspective' Online Journal of Social Sciences Research, Volume 2, Issue 7, pp 214-219,

[36]. Wilmar Schaufeli, 2013, What is engagement in C. Truss, K. Alfes, R. Debridge, A. Shantz, and E. Soane (Eds) Employee Engagement in Theory and Practice, Routledge. 